\title{
The right of the overflown state to divert or intercept civil aircraft under a bomb threat: an analysis with regard to Ryanair flight 4978
}

\author{
Mikko T. Huttunen ${ }^{1}[$
}

Received: 9 July 2021 / Accepted: 13 September 2021 / Published online: 3 December 2021

(c) The Author(s) 2021, corrected publication 2022

\begin{abstract}
The purpose of this article is to discuss whether a state has a right to divert or intercept a foreign civil aircraft flying above its territory, when the aircraft is under a bomb threat. The analysis stems from the recent incident where a Ryanair passenger jet was diverted to Minsk while flying in Belarusian airspace; however, the article approaches the topic from a general perspective, analyzing the key applicable rules of international aviation safety and security law. The article argues that air sovereignty and national rules on aviation (the latter wherever such exist) provide states acting in good faith the right to divert or intercept foreign aircraft for security reasons. Meanwhile, Article 3 bis of the Chicago Convention does not recognize such a right. The right is also limited by international rules that oblige every state to assist aircraft in distress, as well as rules that emphasize the authority and responsibility of the pilot-in-command. Since mid-air interventions are so rare, the legality of states' actions must be analyzed case-by-case. Regardless, the legal regime of international aviation does not allow states to respond to security threats in whatever way they please, especially if the threat is a mere pretext for politically motivated action.
\end{abstract}

Keywords Aviation security · Aviation safety · Aviation law · Air law · ICAO · Chicago convention $\cdot$ Bomb threat $\cdot$ Interception

\section{Introduction}

On 23 May 2021, Ryanair flight 4978, which was on its way from Athens, Greece, to Vilnius, Lithuania, was diverted to the Minsk National Airport, Belarus. The diversion occurred at the request of the Belarusian air navigation service provider (ANSP), Belaeronavigatsia. The reason for the diversion was that, pursuant to an email received by the Minsk Airport, the Islamic resistance movement Hamas

Mikko T. Huttunen

1 Faculty of Law, University of Lapland, Rovaniemi, Finland 
had placed an explosive device on board the Ryanair aircraft. The air traffic control informed the pilot that the bomb can be activated over Vilnius, and so the pilot decided to change the course of the jet to Minsk. The aircraft was then intercepted (approached) and escorted by a Belarusian MiG fighter jet (Belarus Department of Aviation 2021; Tétrault-farber and Osborn 2021). ${ }^{1}$

The threat of the aircraft exploding over the city, however, was in all likelihood a manufactured crisis. When the aircraft was emptied and investigated at Minsk, no bomb was discovered by the Belarusian authorities. According to investigative journalists, there were inconsistencies about the supposed email threat, which was timed after the incident and only properly received by the Minsk airport: the email had been sent to the wrong Lithuanian authorities, and the Greek civil aviation authorities had received no email at all. Furthermore, Hamas immediately denied any participation in the events. Indeed, the reason behind the diversion was most likely that it enabled Belarus to arrest Roman Protasevich, an opposition journalist disliked by the authoritarian Belarusian regime (Weiss 2021).

The core legal question raised by the incident is as follows: which obligations have Belarus or other parties breached in the course of the diversion? This question consists of at least three sub-questions and one auxiliary question:

1) May a state in whose airspace there is a foreign civil aircraft that is under a bomb threat (the overflown state) legally divert or intercept such an aircraft?

2) Can escorting a civil aircraft amount to a threat of force, as forbidden under Article 2(4) of the Charter of the United Nations (UN Charter, 1945; see Stürchler 2007)?

3) Is a state or an individual responsible or liable for providing false information to the pilot of a civil aircraft?

4) What sort of countermeasures can be taken against Belarus in order to prevent similar occurrences in the future?

In this article, I seek to discuss the first of the given four questions: whether the overflown state has a right to divert or intercept a foreign civil aircraft that is under a bomb threat. I will discuss the issue from a general, doctrinal perspective, attempting to present how current law treats these situations. I will use the Ryanair incident as a reference point, despite its peculiarity due to the manufactured nature of the threat.

I will discuss the question with reference to safety and security related international aviation law. The primary instrument under examination is the 1944 Convention on International Civil Aviation (Chicago Convention 1944) and its Annexes, which contain the international standards and recommended practices (SARPs) on aviation safety and security. The SARPs, which are the authoritative international rules on aviation safety and security (see e.g. Havel and Sanchez 2014, 60-64) have

\footnotetext{
1 The reader should note that the transcript of the conversation between the air traffic controller and the Ryanair pilot has not been verified by the International Civil Aviation Organization (ICAO) or any other non-Belarusian authority.
} 
been developed and are constantly revised by the International Civil Aviation Organization (ICAO), also established in the Chicago Convention (Arts 37 and 43-66). The Chicago regime is universal, as the Convention has 193 parties (ICAO 2021).

The other three questions regarding use of force, the provision of false information, and the possibility and legality of countermeasures are left outside the scope of this paper. All of them are crucial topics in the context of the Ryanair incident. However, given the complexity of the issues, including state responsibility (see already Jackson and Tzanakopoulos 2021), their proper treatment will necessitate further, distinct studies.

In terms of legal sources, this article excludes discussing regional (such as those of the EU) rules that apply to such situations. This exclusion stems from two things. First, it is useful to examine international standards because they establish the baseline of security applicable across the world. Meanwhile, an investigation into regional rules is not very informative with regard to the Ryanair incident, as Belarus is not an EU Member State and not subject to EU safety and security standards pursuant to any arrangement. Since acting against civil aircraft concerns each state's sovereign capacity, as is detailed below, domestic air law cannot be entirely disregarded. Still, as the purpose of the article is to assess the international legal situation, national rules will primarily be used as examples. Finally, I will exclude considering the question from the perspective of law outside aviation safety and security. Tackling such would expand the article beyond its reasonable scope.

Bombs are generally regarded as security rather than safety threats: they fall within the ambit of security regulation, such as Annex 17 to the Convention on International Civil Aviation: Security (ICAO 2017). This is mainly an informative distinction on a conceptual level, as in reality the two are difficult to distinguish from each other (see Huang 2009; Huttunen 2020; Mironenko Enerstvedt 2017, 100-101). To paraphrase the common definition of security, I am concerned with actions that unlawfully interfere with the normal operation of the aircraft (see generally e.g. Price and Forrest 2016). Of all security issues, I limit my examination to explosives placed on board aircraft. This is because cases where an aircraft is targeted by anti-air weapons or, more obviously, seized unlawfully can give rise to quite different arguments and conclusions.

\section{Air sovereignty and national rules}

\section{Air sovereignty}

The starting point in analyzing the right of the overflown state to divert civil aircraft, as was done in the Ryanair incident, is the air (aerial) sovereignty of states. As recognized in (but not established by) ${ }^{2}$ the Chicago Convention, "every state has

\footnotetext{
2 This is because air sovereignty is seen as a rule of customary international law rather than something only decided on in the Convention. Indeed, it was already recognized multilaterally prior to the Chicago Convention. For a recent well-written summary, see e.g. Correia 2019.
} 
complete and exclusive sovereignty over the airspace above its territory." The territory in question includes both land areas and territorial waters. (1944, Arts 1-2). This rule or a state of facts, depending on the viewpoint (see Koskenniemi 2005, 224-303), essentially means that the state owns its airspace: it has an exclusive legislative, administrative, and judicial competence (ICAO 2013, 1). States can control which aircraft may access their airspace and how they must behave therein. The default position is therefore that, by virtue of their air sovereignty, the overflown state has the right to divert or intercept foreign civil aircraft that may carry a bomb on board.

On the other hand, sovereignty signifies the ability to enter into international agreements that limit the state's right to exercise such control. States that have opted to join the Chicago Convention and other treaties, such as bi- and multilateral air service agreements (ASAs), have to follow the rules set forth in these arrangements. Their whims are, at least from the legal perspective, restricted (see already Lissitzyn 1953, 586-587).

The concept of air sovereignty, therefore, does not provide definitive answers to questions of international law, such as whether a state has the right to divert or intercept a civil aircraft. Any reference thereto by states that might want to control foreign civil aircraft, like Belarus in the Ryanair incident, must be explored further. We need to also look at the substantive rules that govern the matter (See, again, Koskenniemi 2005, especially 225-226).

One rule that emphasizes air sovereignty is that the Chicago Convention and its SARPs only apply to civil aircraft, not to state aircraft (1944, Article 3. Of the distinction, see ICAO 1994). The latter aircraft, which includes military aircraft like the Belarusian fighter jet, are outside the scope of the Chicago regime. This means that, within the Chicago system of rules, states can neither allow nor forbid the diversion or interception in an exhaustive manner. State aviation, including an act of interception by military aircraft, is a matter falling by default within the ambit of each state's air sovereignty. Rules justifying the diversion or interception or aircraft under a bomb threat are bound to be limited by the given principle.

Another two rules emphasizing air sovereignty are included in Articles 11 and 12 of the Convention. Pursuant to Article 11, the overflown state's laws and regulations on air operations and navigation must be followed by any aircraft that flies above it. This is related to Article 12, which necessitates aircraft to follow the rules of the air in force in the overflown state. Furthermore, SARPs call for states to govern the interception of civil aircraft by regulations and administrative directives (Annex 2 to the Convention on International Civil Aviation, ICAO 2005, para. 3.8). These provisions provide the state with an opportunity to enact laws that require foreign aircraft to land in the overflown state's territory or to be escorted in case of a bomb threat.

As it seems, there are rules that allow action against aircraft under a bomb threat in some (or perhaps many) countries. Using my home country Finland as an example, Section 167 of the Finnish Aviation Act (2014) allows authorities "[f]or reasons of public order and safety [to, inter alia] assign a heading or flight altitude or otherwise intercept an aircraft in flight". The German Aviation Security Act directly states that, in order to prevent a particularly serious accident from occurring, the 
armed forces may force aircraft to change its heading, force it to land, threaten to use armed force, or fire warning shots $(2005, \S 14$, para. 1).

No such rules have been contested at ICAO to my knowledge. Therefore, the starting point is that national air law does in many countries allow the overflown state to take action against aircraft under a bomb threat. This may include a right to divert or even to intercept the aircraft.

Regarding the Ryanair incident, the Belaruian Air Code (2006a) obliges the country's authorities, for example, to take legal measures to prevent and stop violations of the Belaruian Rules of the Air (Art. 15). The latter Rules do justify military intervention (2006b, paras 97-99), but according to my interpretation these only apply to cases where an aircraft enters Belarusian airspace without a permit - the situation recognized in Article 3 bis of the Chicago Convention (1944), as discussed below. It therefore seems that Belarus, like many other countries, finds justification for its actions in its own laws, and that these rules do not seem to violate ICAO's stance on the matter. Of course, in the Ryanair incident this justification appears nothing but a pretense for the underlying political motives. Still, the general point regarding actual bomb threats remains.

\section{Limitations on sovereignty and national rules}

Purely on the basis of the aforementioned, the conclusion would appear clear. States typically have a right based on their national air law to divert and intercept foreign civil aircraft that pose any security threat. And, regardless, interceptive acts performed by military aircraft fall outside the scope of the Chicago regime. The case is not, however, as clear as it might appear. While the Chicago regime does not apply to state aircraft, cases such as the Ryanair incident are not purely about state aircraft: they rather concern the interaction between state and civil aircraft. An interception is made by a state aircraft, but it targets a civil aircraft. This is problematic from the perspective of the regime. On the one hand, the incident falls within the ambit of the regime; on the other hand, it does not.

With regard to national rules, the interaction is equally convoluted. Article 11 of the Chicago Convention (1944), which allows states to apply its laws and regulations to all aircraft in its airspace, is explicitly "[s]ubject to the provisions of [the Chicago] Convention". In the case of Article 12, there is an explicit reference to SARPs established on the basis of the Convention: local rules must be uniform with these rules "to the greatest possible extent". In other words, to put it simply, no state party to the Convention should enact local laws that are inconsistent with the Convention or international safety or security standards. In case they do departure from SARPs, they must immediately notify ICAO about the differences (Article 38).

Therefore, the examination of the question does not end at air sovereignty, the inapplicability of the Chicago regime to state aircraft, or national rules allowing the overflown state to intervene. We must also examine other substantive provisions of the regime that may affect the rights of the overflown state. 


\section{Article 3 bis of the Chicago convention}

\section{Applicability to bomb threats}

Article 3 bis of the Chicago Convention (1944) is one of the provisions that attempts to regulate actions taken against civil aircraft, and the interaction between civil and state aircraft. The drafting history of this particular provision is not related to bombs or other threats of unlawful interference at all. It was included in the Convention in the 1980s due to several occurrences where a civil aircraft was shot down because it accidentally veered into foreign airspace and was wrongly identified as a military aircraft. The triggering incident was Korean Air Lines Flight 007 (See ICAO 1984a, 1984 b, passim. In literature, see e.g. Cheng 1985). ${ }^{3}$ This is apparent from paragraph a) of the provision, which recognizes the duty of every state to refrain from using weapons against civil aircraft - one of the topics excluded from this article.

Still, many commentators have referred to the provision in relation to the Ryanair flight, largely in favor of other provisions (see Jackson and Tzanakopoulos 2021; Miles 2021; Wood 2021, citing John Byerly as the expert). This stems from the wording of paragraph b) of the Article, which indeed is the most important part in the present context:

The contracting States recognize that every State, in the exercise of its sovereignty, is entitled to require the landing at some designated airport of a civil aircraft flying above its territory without authority or if there are reasonable grounds to conclude that it is being used for any purpose inconsistent with the aims of this Convention; it may also give such aircraft any other instructions to put an end to such violations....

This recognizes two cases where every state has the right to require a civil aircraft flying above its territory to land or to give such aircraft other instructions: when the aircraft is flying there without authority or when "there are reasonable grounds to conclude that it is being used for any purpose inconsistent with the aims of this Convention".

Does either of the given conditions apply to a situation where a civil aircraft may be carrying a bomb on board? The authority to enter foreign airspace, first of all, is an utterly distinct question. This is governed by, inter alia, Articles 3(c), 5-7, and 9 of the Chicago Convention (requirement of authorization, scheduled and non-scheduled flights, cabotage, prohibited areas), regional arrangements (like the European Union's single aviation market), and ASAs (see Augustin 1998, 196-197). If an aircraft is allowed into the airspace in the first place, as was the case with Ryanair Flight 4978, it is not flying there unauthorized.

It is a much more complex question whether a possible bomb on board means that the aircraft "is being used for any purpose inconsistent with the aims of the Chicago Convention", thus allowing the overflown state to require landing. The first

\footnotetext{
3 The provision was included through a Protocol, to which 157 out of the 193 states parties to the Chicago Convention (including Belarus) have joined. The Protocol entered into force in 1998 (ICAO 2021).
} 
sub-question one can distinguish from the given question is whether a bomb placed aboard an aircraft is something that is inconsistent with the aims of the Convention.

To answer this question, one is bound to first observe that the phrase "any purpose inconsistent with the aims of this Convention" is a carbon copy of the one used in Article 4 of the Convention (1944, titled "Misuse of civil aviation"). Therein, states agree not to use civil aviation in such a way. Yet, despite the similarity, it has been asserted that "any purpose inconsistent with the aims of this Convention" has a broader meaning in the context of Article 3 bis, and that Article 4 has no bearing on the meaning at all. Arguably, Article 3 bis was intended to cover any breaches of "the law and public order" of the overflown state (ICAO 1986, para. 6.1. See also Abeyratne 2014, 68 and 93; Milde 1986, 125).

In light of the given argument, it must be acknowledged that the scope of the two Articles is different in one respect. Article 4 is an obligation imposed on states "not to use" civil aviation to threaten general security (ICAO 1986, para. 3.1): it does not forbid individuals and non-state entities from doing so (Augustin 1998, 111; Scott and Trimarchi 2020, 43). Meanwhile, Article 3 bis recognizes the right to require landing and so forth when there are reasonable grounds to conclude that a civil aircraft "is being used" by any party in such a way.

This difference, however, simply is about who commits the violation, not what the violation is: the acts falling within the ambit of the two provisions ought to be the same. The difference is only relevant to, inter alia, the matter of state responsibility. Article 4 forms a basis for state responsibility for acts that go against the aims of the Convention (cf. Augustin 1998, 111), whereas paragraph b) of Article 3 bis does not. ${ }^{4}$ This does not affect the interpretation of what is meant by "any purpose inconsistent with the aims of this Convention". With regard to this phrase, I argue that there should be no distinction.

I argue so, inter alia, because any distinction goes directly against the text of the Convention, which is the key factor in any treaty interpretation. (Vienna Convention on the Law of Treaties 1969, Article 31, para. 1). Articles 3 bis and 4 form each other's context in the Chicago Convention; thus, when the same phrase is used in both, one's interpretation must begin from the standpoint that they mean the same thing (Linderfalk 2007, 106-108). Furthermore, the 1984 Executive Committee proceedings regarding the drafting of Article 3 bis stated the following as one of the "main points emerging from the discussion" (as opposed to the views of single countries, which should not be construed as the common will of the parties):

The provision of Article 4 not to use civil aviation for any purpose inconsistent with the aims of the Chicago Convention should be emphasized (ICAO 1984b, 192, emphasis added).

Contrary to the aforementioned claim, this suggests that the phrase in Article 3 bis was intended to buttress the point made in Article 4, not to give it another meaning. The scope in terms of actions covered is the same.

\footnotetext{
${ }^{4}$ To be sure, paragraph $a$ ) of Article 3 bis may establish state responsibility for actions against civil aircraft.
} 
This preliminary discussion, however, provides no answer as to what the scope of the phrase "any purpose inconsistent with the aims of this Convention" is. Now, ICAO itself has suggested that the phrase refers to basically any "threat to the general security", a phrase mentioned in the Preamble of the Convention (ICAO 1986, paras 3.1-3.2; ICAO 1997, para. 3.3). This is a reading supported by literature (Abeyratne 2014, 91 and 93; Milde 1986, 122-123; Scott and Trimarchi 2020, 43). Indeed, Article 4 from which the phrase originates was based on the 1928 KelloggBriand pact (General Treaty for Renunciation of War as an Instrument of National Policy), as noted in the travaux of the Chicago Convention (ICAO 1944, 1381).

However, I am of the opinion that such a reading is perhaps substantively but not formally on point because the preambular phrase "yet its abuse can become a threat to the general security" is difficult to read as an aim of the Convention. The phrase does not set out any attainable goal: it merely acknowledges an unfortunate risk. If we take the concept of "aims" seriously, our primary focus should be on the purposes of the Convention.

In my view, the aims of the Convention include the key positive values mentioned in the Preamble of the Convention, right next to the phrase on general security. ${ }^{5}$ These include, for example, the development of international civil aviation, friendship and understanding among nations and peoples of the world, and the desire to avoid friction and promote cooperation. They do not include the objectives of the $I C A O$, as set forth in Article 44 of the Convention: in terms of treaty interpretation, ICAO's aims are not the Convention's aims, (Augustin 1998, 197; contra Abeyratne 2014, 90-91, though only suggesting that it "may also be useful to refer to Article 44"). In practice, of course, the aims do coincide.

Despite this detour, it would appear that the end result is not much different: goals like "friendship and understanding" or avoiding "friction" are just as broad or even broader than avoiding any "threat to the general security". Quite anything displeasing could be a purpose that causes friction between nations and discourages cooperation between them. Hence, virtually any purpose for which aircraft is used that is somehow damaging and significant enough to have an international effect is a "purpose inconsistent with the aims of this Convention". A bomb threat, especially on a foreign aircraft, is in my assessment an occurrence that meets the given criteria: it is inconsistent with the aims of the Chicago Convention.

\section{The right to divert or intercept}

We have established that a bomb on board a civil aircraft is something that goes against the aims of the Chicago Convention. Does Article 3 bis therefore recognize every state's right to require landing in such cases? To answer this question, it is necessary to still explore two aspects of the Article.

\footnotetext{
5 The matter of determining the aims of any treaty is not exactly a straightforward matter, as elaborated on in literature. Typically, in cases where the treaty has no explicit provision on objectives, these are discovered from the Preamble and other general provision. See e.g. Linderfalk 2007, 203-234
} 
The first of these is the phrase "reasonable grounds to conclude that [the civil aircraft] is being used". This is rather straightforward in the context of bomb threats. If there are only hints about a bomb, the air navigation service provider must assess the credibility of these statements and determine whether they constitute reasonable grounds. Meanwhile, if the ANSP has received a direct bomb threat, reasonable grounds clearly exist. Obviously, "reasonable grounds" refers only to actual threats, delegitimizing actions based on falsified information. As the Ryanair incident demonstrates, the "reasonableness" of the grounds is left for the international community to assess post facto.

The phrase "being used" is more convoluted. Paragraph b) of Article 3 bis only applies when an aircraft "is being used for any purpose inconsistent with the aims of this Convention". This could be read as including scenarios where the user of the aircraft (the operator or the pilot-in-command) is not to blame for what is or has been done to their aircraft. When a hostile party places a bomb on board, whatever mishaps the user of the aircraft then causes are unintentional. Whether such misuse is also covered by Article 3 bis goes back to what is actually meant by the concept of "use": does it refer to anyone doing anything with the aircraft (including the act of placing a bomb therein) or does it only refer to the actions of the operator or the pilot?

This is a matter of treaty interpretation that calls for a contextual reading. From a purely literal standpoint, when an explosive device is placed on board an aircraft, one can say that the aircraft is "being used" to threaten general security. However, this in my opinion should not lead to legal conclusions. It would be tantamount to saying that a civil aircraft facing a surface-to-air missile (another interfering threat) is being used contrary to the aims of the Chicago Convention. This does not make sense. The instrument of crime that is "being used" to create the threat is the bomb placed on the aircraft or the missile aimed at it, not the aircraft. In both scenarios, the aircraft itself is not used in a hostile way: unlike in a hijacking, it is the target or a factual circumstance that increases the threat. If the user of the aircraft is operating bona fide, the use itself is not inconsistent with the peaceful aims of the Convention.

On the basis of all the aforesaid, my argument is that a bomb threat is substantively inconsistent with the aims of the Chicago Convention; however, it is not a case where the aircraft is being used inconsistent with the aims of the Chicago Convention. Therefore, Article 3 bis does not apply to these situations. It does not recognize any right for the overflown state to require a civil aircraft under a bomb threat to land nor to give it any other instructions (contra Jackson and Tzanakopoulos 2021, suggesting a possibility).

Another notion that supports this argument is the purpose of the provision. Article 3 bis was drafted in response to cases where there is a misplaced aircraft whose classification (civil or state) and aims (peaceful or hostile) are unclear, requiring the international community to clarify the overflown state's permissible sphere of action (see, again, ICAO 1984a, 1984b and literature related to the Korean Airlines Flight 007). Hence, there is a reference to the "interception" of the misplaced aircraft. The rules on interception are elaborated on in Appendix 2 and Attachment A of Annex 2 to the Convention on International Civil Aviation (Rules of the Air, ICAO 2005), the Attachment being though of non-binding character (Augustin 1998, 203). The 
provision should not be injected into cases where the aircraft's identity is known and its mission manifestly peaceful, not even when it is under attack.

To apply this reasoning to the Ryanair incident, the Belaruian ANSP had no right based on Article 3 bis to require the jet to land. However, at least pursuant to available information, the air traffic controller (ATCO) did not require the aircraft to land at Minsk: there was only a recommendation to do so (Belarus Department of Aviation 2021; Tétrault-farber and Osborn 2021). As will be seen below, a recommendation to divert to an aerodrome that is not closest to the aircraft is allowed, particularly in a situation where the threat is attributed to the intended, closest aerodrome. Thus, the actions of the ANSP would have been legal if the bomb threat had been real. Since in all likelihood it was not, the recommendation should be further studied as an act of providing false information to civil aircraft.

Since Article 3 bis provides no right to require a foreign civil aircraft to land due to a bomb threat, there is accordingly no right on the basis of that Article to intercept such aircraft. Hence, Belarusian authorities had no right based on Article 3 bis to escort the Ryanair civil aircraft to Minsk by a military aircraft. One is thus left with the conclusion that Article 3 bis does not provide a justification for Belarus's actions.

At the same time, though, Belarus's actions do not seem illegal in light of Article 3 bis. This has to do with the nature of the Article. It does not exhaustively list cases where every state has the right to divert civil aircraft: it merely "recognizes" such a right in one particular case, which does not forbid states from diverting aircraft in other cases. The word "recognize" indicates that the right is part of every state's air sovereignty. The Convention merely codifies the right (see Augustin 1998, 195). To emphasize the link to air sovereignty, the Article issues the aforementioned right to every state "in the exercise of its sovereignty". Other cases are to be decided on the basis of air sovereignty and other related rules.

Naturally, any national rules that allow the overflown state to divert or intercept an aircraft under a bomb threat must also be in accordance with Article 3 bis. But, if the Article does not exclude such action in its own right, it surely does not exclude any state from enacting rules that somehow govern such action. Hence, these rules are not illegal from the perspective of Article 3 bis either.

\section{Other rules of the Chicago regime}

\section{Assisting aircraft in distress}

On the basis of the aforementioned analysis, Article 3 bis neither justifies nor forbids the overflown state to require a civil aircraft under a bomb threat to land nor to give it any other instructions. Yet, Article 3 bis is not the only applicable international rule to bomb threats. In any distress scenario, Article 25 of the Chicago Convention (1944) is of great importance. That provision calls for each state party to undertake to provide assistive measures to aircraft in distress and to allow the authorities of the state of registry to also provide such. The rule is important because it highlights the starting point of any response to any security problem facing an aircraft 
(or safety, for that matter): the overflown states assist aircraft in distress, not issue them orders. The perspective is fundamentally different from the case envisioned under Article 3 bis, where the purpose and status of the aircraft are either unknown or hostile, which places the overflown state under a security threat.

The SARPs on the providers of air traffic services (ATS) follow the same approach: air traffic controllers are required to provide the aircraft in distress the opportunity to take the safest course of action. To paraphrase the relevant rules, states that are parties to the Chicago Convention must provide maximum consideration, assistance, and priority to aircraft that are subjected to unlawful interference. ATS units must attend promptly to requests by the aircraft and take necessary action to expedite all phases of the flight, in particular the landing of the aircraft. They must also inform state authorities and exchange necessary information with the operator (Annex 11 to the Convention on International Civil Aviation, ICAO 2018b, section 2.24).

Albeit security related SARPs chiefly concern measures like screening and response to hijacking, they reflect the same approach. The state responsible for providing ATSs to the aircraft must collect all pertinent information on the flight and transmit it to all other concerned states. Hence, the destination airport ought to be informed about any bomb scares. There is also a recommendation to cooperate with other states for the purpose of providing a joint response, and to exchange information. In terms of assisting the flight, ATS units must advise the crew about threats - as was done in the Ryanair incident (under a false pretense) - and to attend to the requests and anticipated needs of the aircraft. The ATS unit must ascertain what the flight crew intends to do and handle the aircraft as expeditiously as possible while ensuring the safety of other parties. Re-clearances to new destinations must be issued without delay. The ATS unit is not, however, allowed to advice the crew about the bomb itself (Annex 17 to the Convention on International Civil Aviation, ICAO 2017, paras 5.2.2, 5.2.7, and 5.3.2, and section 15.1.3).

Besides Annexes to the Chicago Convention, there are special rules in the Procedures for Air Navigation Services - Air Traffic Management (PANS-ATM) for situations where an ATS unit has received a bomb threat warning. None of these rules either provide the overflown state with any rights. In such situations, inter alia, the unit must follow the aforementioned rules on attending to the requests of the aircraft and on expediting the flight. Additionally, they must ascertain the crew's intentions and report those to other concerned ATS units (ICAO 2016, section 15.1.3).

The conclusion arising from all the given rules is obvious. The overflown state has no right based on international SARPs to force a civil aircraft in distress to land (anywhere). On the contrary, it is obliged to assist the aircraft. The approach of the rules should be viewed as a limitation imposed on states in their behavior toward aircraft under a bomb threat. Any national rules that allow diversion or interception in the case of a security threat should be read in light of the extensive obligations to assist aircraft in distress.

There is no explicit right to intercept aircraft under a bomb threat either. The few rules there are on the interception of civil aircraft ("principles [for which due regard shall be had] when developing regulations"), as included in Appendix 2 of Annex 2 to the Chicago Convention, do not support interception as the default response. The 
key principle is that the "interception of civil aircraft will be undertaken only as a last resort". Another principle is that the default purpose of an interception is determining the identity of the aircraft: other action ought to be taken only when it is necessary to guide the aircraft somewhere (ICAO 2005, para 1.1, subparas a and b).

To apply these softly formulated rules to the Ryanair incident, it seems obvious that the Belaruian action was not appropriate. It was not necessary to guide the Ryanair aircraft anywhere nor instruct it to land. The aircraft was already following the ANSP's recommendation. In the light of all circumstances, it seems that the interception's purpose was simply to intimidate the Ryanair pilot to comply (e.g. Jackson and Tzanakopoulos 2021).

\section{The rights and obligations of the pilot-in-command}

As mentioned, the regulatory approach from a safety and security perspective emphasizes the duties of the overflown state to assist aircraft in distress. This corresponds with the rights and obligations of the pilot-in-command (PIC) of the aircraft. There is no provision in the Chicago Convention about the pilot-in-command's responsibility, liability, or rights - the Convention merely notes that pilots must be certified (1944, Art. 32). According to SARPs, however, the basic principle is that the pilot-in-command is responsible for the safety of passengers, crew, and cargo. (S)he also has responsibility for the operation and safety of the aircraft from the moment of take-off to landing (Annex 6 to the Convention on International Civil Aviation, ICAO 2018a, Part I, para. 4.5.1, concerning the PICs of aeroplanes in commercial air transport).

This responsibility is the primary legal consideration in any occurrence that takes place during the flight of an aircraft. It is emphasized by another rule that imposes upon the PIC the responsibility to follow the rules of the air, unless departing therefrom is "absolutely necessary" for safety reasons. Accordingly, the idea is that the PIC has "final authority as to the disposition of the aircraft while in command." (Annex 2 to the Convention on International Civil Aviation, ICAO 2005, paras. 2.3.1 and 2.4). It is ultimately the pilot, not the air traffic controller, who decides where the aircraft flies in any particular situation, including a case where there is a risk of an explosive device being on board the aircraft. The rules de-emphasize the right of the overflown state to divert or intercept the aircraft.

This is affirmed in the rules of the air regarding unlawful interference. The rule is that, if an aircraft faces unlawful interference, the PIC has an obligation to attempt landing as soon as possible. The PIC must

attempt to land as soon as practicable at the nearest suitable aerodrome or at a dedicated aerodrome assigned by the appropriate authority unless considerations aboard the aircraft dictate otherwise (ICAO 2005, para. 3.7.2).

This standard is rather self-explanatory. When an aircraft is under a bomb threat, the PIC must land at either of the two locations unless another course of action, like 
landing at a specific aerodrome or not landing at all (until the threat is resolved), is dictated by the circumstances.

In the context of the Ryanair incident, it would at first appear that either the PIC or the Belaruian authorities violated the given standard: Vilnius would have been the "nearest suitable aerodrome". However, in that case the appropriate authority assigned Minsk as the "dedicated aerodrome", simultaneously issuing a warning that the bomb could be set off while the aircraft would fly over Vilnius. Had the PIC known the warning to be fabricated to arrest the opposition journalist, one might argue there would have been "considerations aboard the aircraft" to continue the descent toward Vilnius. But, since presumably (s)he did not, there was no violation of security standards on behalf of the pilot.

\section{Conclusions}

The purpose of the present article has been to assess the right of the overflown state to divert (require landing) or intercept a civil aircraft under a bomb threat. In the course of this exercise, the article has noted that states first of all have sovereignty over the airspace above their territory, which supports the overflown state's right to intervene. This is emphasized by the fact that the Chicago Convention and its related standards and recommended practices do not apply to state aircraft: hence, interception by military aircraft is not forbidden. Furthermore, states have an explicit right to enact national rules that allow them to divert or intercept civil aircraft for security reasons.

Despite this, there are international rules that are related to the given scenario. Article 3 bis of the Chicago Convention recognizes the right of every state to require the landing of a civil aircraft flying above its territory in two cases: when the aircraft is flying without authorization and when it is being used for any purpose inconsistent with the aims of the Convention. While placing a bomb aboard a civil aircraft goes against the object and purpose of the Convention, the provision does not apply because in such cases the aircraft is not exactly "being used" for this purpose. It is merely the target of an armed attack rather than the instrument of crime.

Other international rules suggest that a civil aircraft under a bomb threat should be treated as an aircraft in distress. This means that the approach of the overflown state should not be to issue orders to the aircraft but rather to assist the aircraft. SARPs require the air traffic service providers to advise the crew and attend to all the requests of the aircraft in distress, containing also soft principles on when the interception of the aircraft is allowed. These rules are emphasized by rules on the pilot-in-command of the aircraft, the starting point of which is the final authority of the PIC over their aircraft. Correspondingly, the PIC has the final responsibility for safety, which curbs the rights of the overflown state. The ATS provider is there to support the pilot's actions.

On the basis of the analysis, the legal situation is hence far from clear. On the one hand, the overflown state enjoys air sovereignty and has domestic laws in place, allowing it to intervene; on the other hand, international rules emphasize the pilot's authority and the obligation of every state to assist aircraft. Essentially, the conflict 
is the same as with all international law: the persistent discourse between the rights of sovereign states and the international obligations voluntarily undertaken by them. As research demonstrates (Koskenniemi 2005), there is no way out of the given dilemma. The purpose of legal discourse remains to reconcile between the impossible extremes of, one, allowing states to do as they please and, two, imagining that states must find justification for all of their actions from international law.

The application of rules that allow intervention is luckily so rare that the matter of what the overflown state can legally do boils down to a case-by-case analysis. The Ryanair incident is, of course, peculiar in that it is plagued by the fact that the bomb threat was in all likelihood a manufactured one. The analysis above hence comes with the major caveat that, if there is no real bomb threat, then the overflown state naturally lacks any safety or security-based justification for its actions. And, if there is no such nor other legally valid justification, then the only justification a state may find for its actions is its sheer air sovereignty: some kind of a residual power in accordance with the (in)famous phrase penned by the Permanent Court of International Justice in the 1920s:

"The rules of law binding upon States ... emanate from their own free will ...

Restrictions upon the independence of States cannot ... be presumed." (The

Case of the S.S. "Lotus", 1927, 18).

Such a residual justification appears unconvincingly apologetic in a world where states are increasingly interdependent through international civil aviation. It is understandable that states wish to protect their national security from any kind of unlawful interference in aviation, for which reason intervening in actual bomb threats can be justifiable. Yet, for the global system of civil aviation to function predictably, safely, and securely, the primary responsibility and duty of all states is to provide all possible assistance to civil aircraft under distress to resolve any threats and avoid exacerbating the situation with their own actions. The states' right to intervene with foreign civil aircraft is not and must not be unlimited.

Funding Open access funding provided by University of Lapland.

Open Access This article is licensed under a Creative Commons Attribution 4.0 International License, which permits use, sharing, adaptation, distribution and reproduction in any medium or format, as long as you give appropriate credit to the original author(s) and the source, provide a link to the Creative Commons licence, and indicate if changes were made. The images or other third party material in this article are included in the article's Creative Commons licence, unless indicated otherwise in a credit line to the material. If material is not included in the article's Creative Commons licence and your intended use is not permitted by statutory regulation or exceeds the permitted use, you will need to obtain permission directly from the copyright holder. To view a copy of this licence, visit http://creativecommons.org/licen ses/by/4.0/.

\section{References}

Abeyratne RIR (2014) Convention on international civil aviation: a commentary. Springer, Cham Augustin J V (1998) ICAO and the Use of Force Against Aerial Intruders. Master's Thesis. Institute of Air and Space Law, Faculty of Law, McGill University, Montreal 
Belarus Department of Aviation (2021) About the incident with the emergency landing of the RyanAir plane. Google Translation. http://caa.gov.by/ru/news-ru/view/1-203/. Accessed 24 Jun 2021

Belarusian Air Code (Воздушный кодекс республики беларусь, 117-W). 16 May 2006a, as amended

Belarusian Rules of the Air (Правила использования воздушного пространства Республики Беларусь). Decision of the Council of Ministers of the Republic of Belarus, no. 1471. 4 November 2006b, as amended

Charter of the United Nations (UN Charter). Adopted 26 June 1945, 1 UNTS XVI

Cheng B (1985) The destruction of KAL flight KE007, and article 3 bis of the Chicago convention. In: Storm van's Gravesande J W E, van der Veen Vonk A (eds) Air worthy: liber Amicorum Honouring Professor Dr. I.H.Ph.I. Diederiks-Verschoor. Kluwer, Deventer, pp 47-74

Convention on International Civil Aviation (Chicago Convention) Adopted 7 December 1944, 15 UNTS 295

Correia V (2019) The legacy of the 1919 Paris convention relating to the regulation of aerial navigation. In: Mendes de Leon P, Buissing N (eds) Behind and beyond the Chicago convention: the evolution of aerial sovereignty. Kluwer Law International, Alphen aan den Rijn, pp. 3-23

Finnish Aviation Act (ilmailulaki, 864/2014). 7 November 2014, as amended

General Treaty for Renunciation of War as an Instrument of National Policy (Kellogg-Briand Pact). Adopted 27 August 1928, 94 LNTS 57

German Aviation Security Act (Luftsicherheitsgesetz). 1 November 2005, as amended

Havel BF, Sanchez GS (2014) The principles and practice of international aviation law. Cambridge University Press, Cambridge

Huang J (2009) Aviation safety and ICAO. Kluwer Law International, Alphen aan den Rijn

Huttunen MT (2020) Safety and security of unmanned aircraft systems: legislating sociotechnical change in civil aviation. University of Lapland Press, Rovaniemi

ICAO (2018b) Annex 11 to the Convention on International Civil Aviation: Air Traffic Services, 15th edition

ICAO (2017) Annex 17 to the Convention on International Civil Aviation: Security - Safeguarding International Civil Aviation against Acts of Unlawful Interference, 10th edition as amended

ICAO (2005) Annex 2 (n.d.) to the Convention on International Civil Aviation: Rules of the Air, 10th edition as amended

ICAO (2018a) Annex 6 (n.d.) to the Convention on International Civil Aviation: Operation of Aircraft, Part I - International Commercial Air Transport - Aeroplanes, 11th edition

ICAO (1944) Proceedings of the International Civil Aviation Conference. Department of State Publication 2820

ICAO (1984a) Doc 9437: Assembly 25th Session (Extraordinary) Plenary Meetings Resolutions and Minutes. Montreal, 24 April - 10 May 1984

ICAO (1984b) Doc 9438: Assembly 25th Session (Extraordinary) Executive Committee Report, Minutes and Documents Montreal, 24 April - 10 May 1984

ICAO (1986) C-WP/8217: Secretariat Study on "Misuse" of Civil Aviation

ICAO (1994) LC/29-WP/2-1: Secretariat Study on "Civil/State Aircraft". Legal Committee 29th Session. Montreal, 4-15 July 1994

ICAO (1997) C-WP/10588: Misuse of Civil Aviation (Request from Cuba)

ICAO (2013) ATConf/6-WP/80: airspace sovereignty. Worldwide Air Transport Conference, 6th Meeting. Montreal, 18-22 March 2013

ICAO (2016) Doc 4444: Procedures for Air Navigation Services - Air Traffic Management (PANS-ATM), 16th edition

ICAO (2021) Current lists of parties to multilateral air law treaties. https://www.icao.int/secretariat/legal/lists/ current\%20lists\%20of\%20parties/allitems.aspx. Accessed 9 Jul 2021

Jackson M, Tzanakopoulos A (2021) Aerial Incident of 23 May 2021: Belarus and the Ryanair Flight 4978. EJIL: Talk! Blog of the European Journal of International Law. https://www.ejiltalk.org/aerial-incidentof-23-may-2021-belarus-and-the-ryanair-flight-4978/comment-page-1/. Accessed 1 Jun 2021

Koskenniemi M (2005) From apology to utopia: the structure of international legal argument, reissue. Cambridge University Press, Cambridge

Linderfalk U (2007) On the interpretation of treaties: the modern international law as expressed in the 1969 Vienna convention on the law of treaties. Springer, Dordrecht

Lissitzyn OJ (1953) The treatment of aerial intruders in recent practice and international law. Am J Int Law 47(4):559-589

Milde M (1986) Interception of civil aircraft vs. misuse of civil aviation (background of amendment 27 to Annex 2). Ann Air \& Space Law 11:105-130 
Miles C (2021) Belarus and the hijacking of Ryanair flight FR4978: a preliminary international law analysis. Lawfare Blog. https://www.lawfareblog.com/belarus-and-hijacking-ryanair-flight-fr4978-preliminaryinternational-law-analysis. Accessed 1 Jun 2021

Mironenko Enerstvedt O (2017) Aviation security, privacy, data protection and other human rights: technologies and legal principles. Springer, Cham

Price JC, Forrest JS (2016) Practical aviation security: predicting and preventing future threats, 3rd edn. Elsevier, Oxford

Scott BI, Trimarchi A (2020) Fundamentals of international aviation law and policy. Routledge, London and New York

Stürchler N (2007) The threat of force in international law. Cambridge University Press, Cambridge

Tétrault-farber G, Osborn A (2021) 'They say code is red': transcript of controller telling plane to land in Minsk. https://www.reuters.com/business/aerospace-defense/they-say-code-is-red-transcript-controllertelling-plane-land-minsk-2021-05-25/. Accessed 31 May 2021

The Case of the S.S. "Lotus". 7 September 1927. Publications of the Permanent Court of International Justice, Series A., No. 10

Vienna Convention on the Law of Treaties (VCLT). Adopted 23 May 1969, 1155 UNTS 331

Weiss M (2021) 'Bomb Threat' That Justified Belarus Hijacking Came 24 Minutes After. https://www. thedailybeast.com/bomb-threat-cited-in-belarus-hijacking-came-24-minutes-after. Accessed 31 May 2021

Wood G (2021) The Ryanair hijacking pierced the delusion of flight. The Atlantic. https://www.theatlantic.com/ideas/archive/2021/05/belarus-ryanair-hijacking/619028/. Accessed 1 Jun 2021

Publisher's note Springer Nature remains neutral with regard to jurisdictional claims in published maps and institutional affiliations. 